\title{
Clinical cases of atypical and severe botulism
}

\author{
O. L. Ivakhiv ${ }^{A, E, F}, N$. U. Vyshnevska*B,C,D \\ I. Horbachevsky Ternopil National Medical University, Ukraine
}

A - research concept and design; B - collection and/or assembly of data; C - data analysis and interpretation; D - writing the article;

$\mathrm{E}$ - critical revision of the article; $\mathrm{F}$ - final approval of the article

The aim of the work was to present two clinical cases of botulism: the atypical course and the severe course with late administration of heptavalent botulinum antitoxin, which still had a significant positive clinical effect and contributed to a faster recovery of patients.

The modern scientific literature regarding botulism was analyzed, hospital records of patients with botulism were presented.

Conclusions. Characteristic symptoms of botulism are sometimes absent, for example, the inability to read the fine print, which is a significant challenge in diagnosing the disease. Atonic tetraparesis, dysmetabolic polyneuropathy of the lower extremities may be occasionally developed as a complication of botulism. In suspected case of botulism, even with a fuzzy epidemiological anamnesis and an unusual clinical picture, a targeted, specific examination and immediate administration of antitoxins are indicated. The heptavalent botulinum antitoxin has a significant clinical effect, contributes to recovery even at the late stages of a patient hospitalization.

\section{Клінічні випадки нетипового та тяжкого перебігу ботулізму}

\section{0. ^. Івахів, Н. Ю. Вишневська}

Мета роботи - описати два випадки ботулізму: перший з атиповим перебігом недуги, другий - 3 тяжким перебігом і пізнім введенням гептавалентного ботулінічного антитоксину, що врешті дало помітний позитивний клінічний ефект і сприяло швидшому одужанню пацієнтів.

Здійснили аналіз та узагальнення відомостей сучасної наукової літератури про ботулізм, вивчили медичні картки стаціонарних хворих на ботулізм.

Висновки. При ботулізмі іноді відсутні характерні симптоми, наприклад, неможливість читати дрібний шрифт, що суттєво утруднює діагностику недуги. Млявий тетрапарез, дисметаболічна полінейропатія нижніх кінцівок часом можуть виникати як ускладнення ботулізму. Якщо є припущення про наявність ботулізму, навіть при нечіткому епідеміологічному анамнезі та нетиповій клінічній картині, показане цілеспрямоване специфічне обстеження та негайне введення антитоксинів. Навіть у пізні терміни надходження пацієнта у стаціонар введення гептавалентного ботулінічного антитоксину має виражену клінічну ефективність, сприяє одужанню.

\section{Клинические случаи нетипичного и тяжелого течения ботулизма}

\section{О. ^. Ивахив, Н. Ю. Вишневская}

Цель работы - представить два случая ботулизма: первый с атипичным течением болезни, второй - с тяжелым течением и поздним введением гептавалентного ботулинического антитоксина, что все же имело заметный положительный клинический эффект и способствовало более быстрому выздоровлению пациентов.Проведен анализ и обобщение данных современной научной литературы о ботулизме, изучены медицинские карты стационарных больных с ботулизмом.

Выводы. При ботулизме иногда отсутствуют характерные симптомы, например, невозможность читать мелкий шрифт, что существенно затрудняет диагностику болезни. Вялый тетрапарез, дисметаболическая полинейропатия нижних конечностей иногда могут возникать как осложнение ботулизма. При подозрении на ботулизм, даже при нечетком эпидемиологическом анамнезе и нетипичной клинической картине, показано целенаправленное специфическое обследование больного и немедленное введение антитоксина. Даже в поздние сроки поступления пациента в стационар введение гептавалентного ботулинического антитоксина имеет выраженную клиническую эффективность, способствует выздоровлению.

Botulism is an acute form of poisoning with a severe damage to nervous system with disturbances of vision, swallowing, speech, intestinal motility, a weakness of skeletal and smooth muscle, caused by the neurotoxin produced by Clostridium botulinum (serotypes A, B, C1, C2, D, E, F, G). Different serotypes of Clostridium botulinum are distributed in different areas. Foodborne botulism, attributed to A, B, or $E$ toxin, is most frequently found in Ukraine. More often there is foodborne botulism, but wound (in injecting drug users and newborns) [1-3], iatrogenic (when applying botulotoxin for cosmetic procedures, treatment of muscle contracture or endoscopic administration in achalasia) $[4,5]$ and inhalation botulism [1] are also reported. Botulinum neurotoxins can be used as biological weapons [1,2].

Every year, tens of thousands of botulism cases are registered in the world, but the actual incidence is much higher. Botulism occurs much more often in countries where home-preserved vegetables, fruits, fish, meat and
Key words: botulism, ophthalmoplegia, diagnosis, antitoxins, treatment.

Zaporozhye medical journa 2020; 22 (2), 281-286

${ }^{*}$ E-mail: vyshnevska@tdmu. edu.ua

Кнючові слова: ботулізм, офтальмоплегічний синаром, Аіагностика, антитоксин, лікування.

Запорізький медичний журнал. 2020. T. 22, № 2(119). C. $281-286$

Ключевые слова: ботулизм, офтальмоплегический Синаром, Аиагностика, антитоксин, мечение.

Запорожский медицинский журнал. 2020. T. 22, № 2(119).

C. 281-286 


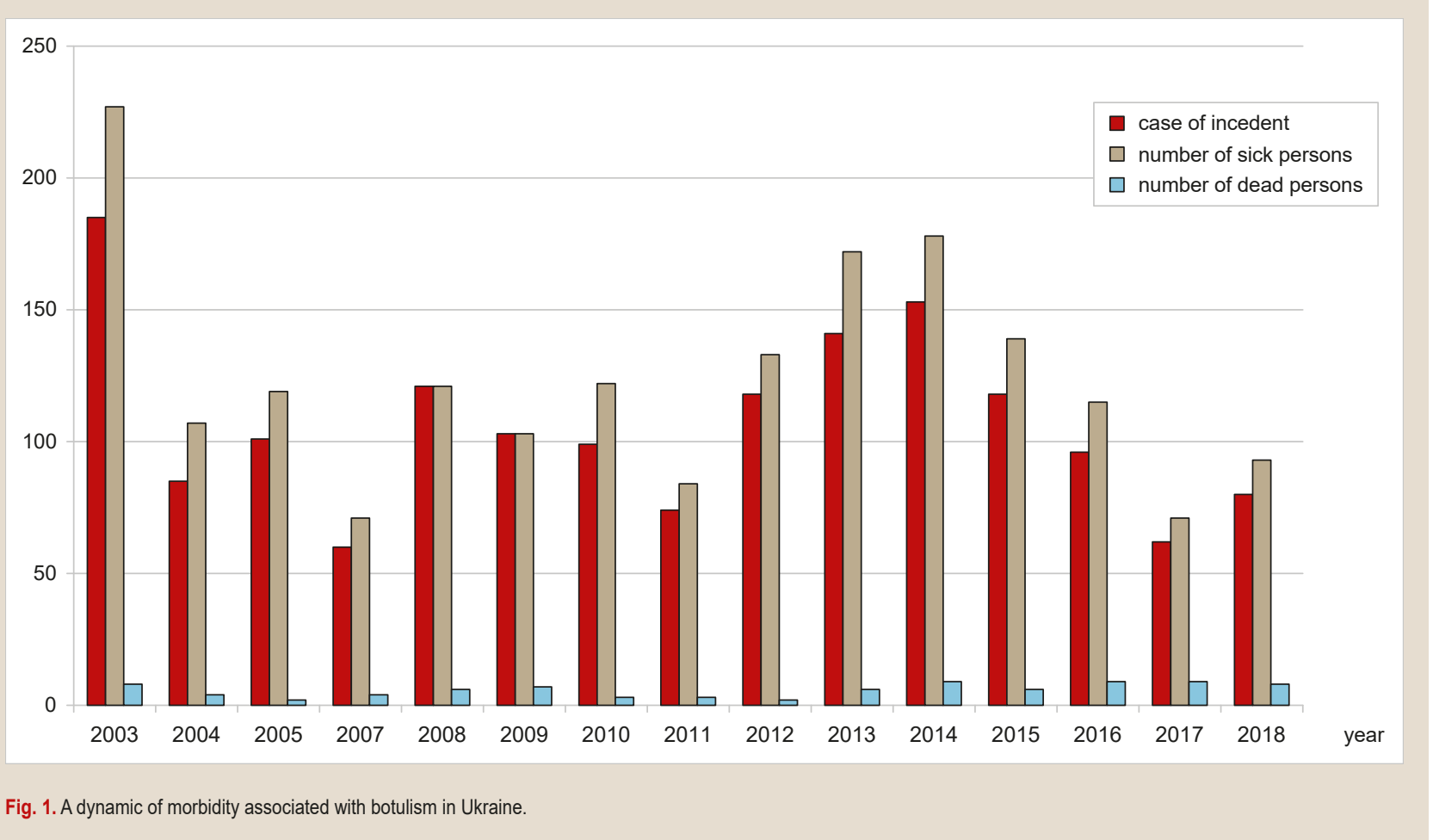

cheese products are traditionally cooked [6], often with a violation of the appropriate technology. There are also known group diseases when using products manufactured by industrial enterprises (commercial and restaurant food in vacuum packaging, including products in hermetically sealed cans) [7].

In some cultures, such as among the indigenous people of Alaska, preferred food preparation practices involving fish fermentation commonly lead to botulism [8]. In China, homemade fermented beans are the leading cause [9]. Commercial foods and restaurants are still occasional sources [10]. In the US, 263 cases of foodborne botulism occurred from 1990 to 2000 (17-43 cases per year) [11]. In 2014, 15 cases of foodborne intoxication were reported in the US. [12]. Foodborne botulism is uncommon in the UK [13]. More cases are seen in Southern and Eastern Europe, where it is more common to preserve foods at home [14]. In England and Wales between 1980 and 2013, there were 36 Health Protection Agency (HPA) reported cases of foodborne botulism including 3 deaths. Of these cases, an outbreak occurred in 1989 with 26 cases and one fatality associated with the consumption of contaminated hazelnut yoghurt [15].

In Ukraine, the epidemic situation with respect to botulism remains unsatisfactory. So, from 225 (2003) to 70 (2007) cases of botulism were registered annually from 2003 to 2018 . As of $1.10 .2018,93$ patients with botulism were registered in Ukraine, 8 of them died. The dynamic of morbidity associated with botulism in Ukraine is shown in the diagram (Fig. 1).

\section{Aim}

The aim of the study was to present two clinical observations of botulism: the atypical course and the severe course with late administration of heptavalent botulinum antitoxin, which still had a significant positive clinical effect and contributed to a faster recovery of patients.

\section{Materials and methods}

The modern scientific literature regarding botulism was analysed and our own clinical observations were presented.

\section{Case presentation 1}

A patient K., 36 years old (case history 1/5476), a resident of a village, a teacher, was hospitalized in the infectious department of the Berezhany Central District Hospital (CDH) on 10.17.2017 on day 3 of the illness with complaints about general weakness, severe mouth dryness, dysphonia, dysarthria, difficulty swallowing, vision impairment, dizziness, urinary retention.

She got sick on 15.10.17, about 10 p.m., with sudden-onset multiple vomiting and diarrhea. The following day, body temperature increased to $38.4{ }^{\circ} \mathrm{C}$, followed by dizziness, dry mouth, difficulty swallowing, blurred vision and diplopia. She sought medical help and was hospitalized with a suspicion of botulism in $\mathrm{CDH}$ on 17.10 at 00 a.m. Due to the patient's severe condition, a consultant-infectionist was called, a magnetic resonance imaging of the head was recommended, and blood was taken on a biological test. However, focal or diffuse lesions, mass lesions, traumatic brain damage were not detected. On 18.10.17, about 5 p.m., the patient was hospitalized in the infectious department of the Ternopil City Municipal Emergency Hospital (TCMEH) with suspicion of botulism, enterovirus infection, meningoencephalitis. Heptavalent botulinum antitoxin (HBAT) was administrated immediately.

According to epidemiological anamnesis, the disease occurred a few hours after a feast; meals were cooked by 
the patient: smoked ham, baked fish, herring, and smoked sausages in a vacuum package. She ate food with her family. In addition, the housewife tasted the ham from the freezer, but she did not like it and nobody else ate it. Everyone around was healthy. Leftovers of food were not laboratory tested. The patient has suffered from myopia since childhood.

Upon admission to TCMEH, the general condition of the patient was severe. Skin and mucous were clean, the face was pale, herpes labialis. She had the expressed dryness of the oral cavity mucous and tongue. Dilated pupils were minimally reactive to light, anisocoria OD>OS, horizontal nystagmus and moderate bilateral ptosis were observed. There was no diplopia. Convergence was reduced, but she read the fine print. The throat reflex was decreased. There was difficulty swallowing solid food.

Pulse was 98 per 1 minute, rhythmic. Blood pressure was $120 / 80-80 / 50 \mathrm{~mm} \mathrm{Hg}$. The heart activity was rhythmic too. Breathing in the lungs was vesicular, somewhat weakened. Abdomen was soft, moderately painful on palpation, with active peristalsis. The liver was soft, elastic and tender, palpated $0.5-1.0 \mathrm{~cm}$ below the right costal margin. The spleen was not palpable. Meningeal signs were absent. Urination was normal. The patient had defecated last time on 16.10.17.

At 8 p.m., the patient started developing signs of respiratory distress (tachypnoe up to 24 per $1 \mathrm{~min}$ ) and she was transferred to the department of intensive care. On arrival, there were such symptoms as abdominal and lower back pain, nausea, diplopia, moderate bloating, decreased intestinal peristalsis. Intravenous infusion therapy was adjusted, nasogastric tube, urinary catheter were inserted. The treatment was administered: denicef, reosorbilact, glycosteryl, Hartmann solution, enterosgel through the tube, dexamethasone, nexium, L-lysine escinate, lasix, purified sodium bicarbonate enema.

Hepatosplenomegaly and signs of pancreatitis were detected in ultrasonographic examination of the abdominal cavity. The results of the other instrumental and laboratory methods of investigation were without peculiarities.

On 19.10 .17 at 9.30 a.m., the Consilium formulated the diagnosis: a suspicion of botulism, a severe course with pronounced ophthalmoplegic and nasogosopharyngeal syndromes. Meningoencephalitis of unclear genesis. Metabolic cardiomyopathy. On the examination: weakness of neck flexor muscles, the Kernig's sign was negative.

Around 11 a.m., a lumbar puncture was performed with diagnostic purpose, liquor was taken for examination (indicators of liquor were in the normal range). Later, from 12.30 to 2 p.m., HBAT (A, B, C, D, E, F, G) was administered intravenously according to the manufacturer's instructions via infusomat, slowly (it had only been received on the 5th day of illness!).

On the same day, the patient was examined by an ophthalmologist: reduced pupillary light response, initial cataract, angiospasm of the retina of both eyes, and by an ENT specialist: dryness and hyperemia of the mucous of the mouth and tongue, decreased mobility of the soft palate. Diagnosis: Botulism? Acute pharyngitis, right-sided lymphadenitis. She was examined by a neurologist: dysmetabolic polyneuropathy of the lower extremities, indolent ataxia.
On 20.10.17, a positive result of the biological test was obtained (Botulinum toxin neutralization reaction in white mice) - botulinum toxin type $B$ was revealed, that confirmed the clinical diagnosis of botulism.

Despite the administration of HBAT, intermittent diplopia, anisocoria, mydriasis, ptosis, decreased photoreaction, snuffling voice, and other neurological symptoms remained.

On 24.10.17, with some improvements in the general condition of the patient, severe pharyngitis and right-sided submandibular lymphadenitis were revealed. According to the ultrasound, both parotid salivary glands were without pathological changes, homogeneous, not enlarged; an enlarged hypoechogenic lymph node of $14 \times 30 \mathrm{~mm}$ in the right area of the lower jaw angle was seen; single unchanged neck lymph nodes up to $12 \mathrm{~mm}$ in size were visualized bilaterally.

On 25.10.17 the patient was transferred to the infectious department. General condition was moderately severe. On 24.10-1.11, the examination revealed a sore throat, moderate general weakness, elevated body temperature (37.4-38. ${ }^{\circ} \mathrm{C}$ within 5 days), purulent pharyngitis, candidiasis, painful submandibular lymph nodes up to $3 \mathrm{~cm}$ in diameter. Liver $+2 \mathrm{~cm}$, soft, elastic, non-tender. Defecation was normal. On 30.10 , a gynecologist diagnosed candidal colitis. Candida fungi were identified in the oropharynx.

With the expansion of the regimen (from 7.11), the lower extremities weakness, a tingling of the left leg, a walking spasm worsened. Ataxic gait was noted. Strength was preserved in all groups of limb muscles. Tendon and periosteal reflexes of the lower extremities were $D=S$, tone in the limbs was reduced. The arm strength was 3.5-4.0 points, the footsteps strength -3 points. There was a hypoalgesia in the distal parts of the extremities, slurred speech. The diagnosis was made: botulism (type B), complicated by flaccid tetraparesis (upper and lower extremity moderate weakness), dysmetabolic polyneuropathy of the lower extremities.

The patient received treatment: bed regime, dietary menu number 4,1 dose HBAT (A, B, C, D, E, F, G); detoxification therapy - glucose, cytoflavin, reosorbilact, dexamethasone $8 \mathrm{mg}$, glycosteryl, Hartmann solution; antibiotics (ceftriaxone, levofloxacin, azithromycin, diflucan); MaxiSorb, B vitamins, proserin, beriliton, proxyum, tyvortin, thiotriazoline, valargin, neuromidine, ATP, lacium, denizef, enterosgel (through a tube), nexium, lasix, I-lysine escinate.

On 20.11.17, the patient was transferred to the neurological department for further rehabilitation, where she was until 7.12.17. During her being there, she had weakness in the arms and legs, walking difficulty, numbness of the left foot, pain in all trunk and extremity muscles, headache, dizziness, grey-out, general weakness, rapid fatigability, and intermittent fever. In the neurological status she had: palpebral fissure and pupils $\mathrm{D}=\mathrm{S}$, active pupillary reaction to light, eye movements were in all cardinal directions, slightly sensitive trigeminal points bilaterally, nasolabial folds $\mathrm{D}=\mathrm{S}$, the tongue was in midline. She had mild dysphagia, dysarthria, dysphonia. Throat reflexes were saved. The uvula was turned to the right. Upper extremity deep tendon and periosteal reflexes were hypoactive, $\mathrm{D}=\mathrm{S}$; abdominal moderately active, $D=S$; knee and Achilles tendon reflexes poor, $D=S$; brisk sole reflex, $D=S$. Mild foot hyperesthesia. The arm muscular strength was reduced to 4 points, 
the proximal lower extremity strength was 3.0-3.5 points. The legs were tender to palpation. The Strumpell's sign was (+) bilaterally. Vibration sensation in limbs was 10-12 sec. She did coordinate tests well. Treatment was prescribed: neurobion, actovegin, mediatorn, keltikan, tiocetam. The dynamics of neurological symptomatology was insignificant; the condition was considered as a complication of botulism. In total, she spent in the hospital 50 bed-days.

\section{Case presentation 2}

Patient Ch., 62 years old (case history 2/343), inhabitant of city, was hospitalized in the infectious department of TCCEH on March 4 2019, on the 5th day of the illness with complaints of general weakness, severe mouth dryness, dysphonia, dysarthria, difficulty swallowing, vision impairment - diplopia and cloudy vision, constipation.

He became ill suddenly at night on 28.02.19 with nausea and multiple vomiting followed by diarrhea a few hours late. On the next day, he presented a general weakness, dizziness, the body temperature was normal. Only on 3.03.2019, the patient developed severe mouth dryness, difficulty swallowing and voice changes (hoarse, nasal), there was diplopia, blurred vision. He sought medical help only on 4.03.2019, as he could not swallow. The patient was admitted to the infectious department with the suspicion of botulism. On admission, the blood was taken for a biological test and a stomach tube lavage was done. HBAT was ordered.

According to the epidemiological anamnesis, the disease occurred in a few hours after home-made pork pate consumption. As its taste appeared strange to him, he ate only half the canned food and throw out the rest in the garbage. He was the only one eating the meal.

The patient was admitted with extremely severe general condition. Skin and mucous membranes were clean without rash, skin sloughing of the shoulders and back, the face was pale. There was a severe dryness of the oral mucous membrane and tongue. Dilated pupils were minimally reactive to light, anisocoria OD>OS, strabismus were observed. Corneal reflex was absent. Nystagmus and ptosis were absent (these symptoms occurred only a day after hospitalization). Convergence and accommodation were reduced; he could not read the fine newspaper print and had diplopia.

Pharynx reflex was absent. He could swallow neither liquid nor solid food. Pulse was 98 per 1 minute. Blood pressure was $130 / 80 \mathrm{~mm} \mathrm{Hg}$. The activity of the heart was rhythmic. Breathing in the lungs was weak vesicular. The abdomen was soft, not painful to palpation, without peristalsis. The liver was soft, elastic and tender, palpated $1.0 \mathrm{~cm}$ below the right costal margin. The spleen was not palpated. Meningeal signs were absent. Urination was normal. The patient had defecated three days ago.

The diagnosis was made: Botulism, foodborne, ophthalmoplegic, phono-laryngoplegic syndromes, and severe course.

He was examined by the following specialists: neurologist, ophthalmologist and ENT, the latter diagnosed paralysis of the epiglottis, soft palate and vocal cords. Due to the severity of the patient's condition, he was transferred to an intensive care department. Intravenous detoxification infusion therapy was adjusted, nasogastric tube, urinary catheter were inserted. Hepatosplenomegaly and signs of pancreatitis were detected in an ultrasonographic examination of the abdominal cavity. The results of the other instrumental and laboratory methods of examination were without peculiarities.

On 9.03.19, a positive result of the biological test (a reaction of botulinum toxin neutralization in white mice) was obtained - a toxin type B was revealed, that confirmed the clinical diagnosis of botulism. There were not significant deviations from the norm in the results of generally accepted laboratory studies.

On 5.03.2019, from 5 a.m. to 7 a.m. (on the 6th day of the illness), HBAT (A, B, C, D, E, F, G) was injected (according to the manufacturer's instruction). In 3-4 hours after the administration of HBAT, the patient's general state was improved, although the ophthalmic and neurological symptoms remained. In 2 days, the patient was transferred to the infectious department. The general condition was stable. Nasogastric rube feeding was discontinued a week after moving to a hospital. There was moderate general weakness and a little decrease in dryness of the oropharyngeal mucous, pupil reaction to light was better. Urination was unassisted, diuresis was normal, defecation was after cleansing enema.

The treatment was administered: bed regime, dietary menu number 4 , loraxon (cefriaxone), reosorbilact, Hartmann solution, glucose solution, enterosgel through the tube, dexamethasone, neuramidine, ATP, neurobion (group B vitamins), cleansing enema, HBAT (1 dose).

In 14 days after the treatment initiation, a significant positive dynamics of neurological and eyes changes was evident: palpebral fissure and pupils $\mathrm{D}=\mathrm{S}$, active pupillary reaction to light, eye movements were in all cardinal directions, nasolabial folds $D=S$, the moist tongue was in midline. He had mild dysphagia, dysarthria, dysphonia. Throat reflexes were saved. The uvula was slightly turned to the right. He was discharged in a satisfactory condition to the home under the supervision of a family doctor.

\section{Discussion}

The incubation period in foodborne botulism may be from several hours to 10 days, on average lasts $51.01 \pm 4.78$ hours [11], and in the wound - somewhat longer, 5-14 days. Most commonly, if the incubation period is shorter, the disease course is more severe. The incubation period was very short in both our patients - several (6-8) hours, so the disease was severe. However, for botulotoxin serotype $\mathrm{E}$, this pattern is not always observed - the onset is usually gradual due to the need for pre-activation of protoxin by gastric enzymes.

Clinical manifestations of botulism are quite diverse, especially in the first hours and days of the disease, even in individuals with a group outbreak, which is largely caused by both the total infective dose and the type of toxin. The most common symptoms are dysphagia (48-66 \%), proximal muscle weakness of upper and lower extremities (60-73\%), neck flexor muscle weakness (33\%), ophthalmoplegia (mydriasis, anisocoria, absence or sluggish reaction to light, convergence insufficiency) (53\%), bilateral ptosis (46\%), dysarthria (53-76\%), diplopia (32-40\%), blurred vision (33-40\%), and mouth dryness (20\%). In patients 
with documented wound botulism, the pupils were reactive in $46 \%[2,13,14]$. Dizziness, rapid fatigability, nausea are also common for foodborne botulism [11]. Due to the polymorphism of symptoms, botulism is often diagnosed late.

The same clinical symptoms (described above) were present in our patients. The first examined patient complained of general weakness, severe mouth dryness, dysphonia, dysarthria, difficulty swallowing, vision impairment, dizziness. Thus, atypical variant of this botulism case was in the dissociation of ophthalmoplegic syndrome: in the presence of moderate ptosis, diplopia, mydriasis, anisocoria, accommodation insufficiency, the patient could read even the fine print and write.

The clinical symptoms of botulism in the second patient were typical too (general weakness, severe mouth dryness, dysphonia, dysarthria, difficulty swallowing, and constipation). But later on, there was a period of relative well-being, when only general weakness was observed, so the patient did not seek medical help, and such characteristic signs of botulism as vision impairment - diplopia and cloudy vision, mouth dryness and difficulty swallowing peveloped on the 4th day of the disease. Severe course of botulism resulted from a delay in seeking care and hospital admission only on the 5th day of the disease.

All patients with botulism and with suspicion of it, regardless of the condition severity, are the objects to immediate hospitalization, as the disease course and complications are fleeting and unpredictable, and the mortality rate is quite high now in case of delayed provision of medical aid.

Supportive care is the mainstay of therapy for botulism. Patients with suspected or confirmed botulism should undergo serial vital capacity assessments in the ICU. In addition, patients should be assessed for the adequacy of gag and cough reflexes, oropharyngeal secretions, oxygen saturation, and inspiratory force should be monitored. Mechanical ventilation should be considered for any patient with upper airway compromise (due to pharyngeal muscle paralysis) or a decline in vital capacity.

Gastric lavage may be attempted in adults regardless of the sick day. In the absence of an ileus, enemas or cathartic agents may be used to eliminate unabsorbed toxin from the gastrointestinal tract. Gastric lavage and/or enemas are not recommended in infants, as well as enterosorbent treatment to remove the toxin that has not yet been absorbed. These manipulations were also performed for our patients.

The only specific treatment for botulism is the administration of botulinum antitoxin. Antitoxin can arrest the progression of paralysis and reduce the duration of paralysis and requirement of mechanical ventilation. Antitoxin should be given early in the course of illness, ideally $<24 \mathrm{~h}$ after onset of symptoms [16-18], because antitoxin neutralizes only toxin molecules that are yet unbound to nerve endings.

The potential for anaphylaxis, delayed allergic reactions (serum sickness), and lifelong sensitization to equine proteins, in addition to short half-lives, limits the use of antitoxins derived from equine plasma (such as HBAT) in the infant (<1 year) population [19].

Different countries may have different types available [13-15]. Infants < 1 year of age should receive the intravenous botulinum immunoglobulin (human), also known as BabyBIG ${ }^{T M}$. Human-derived botulinum immunoglobulin is preferred in the infant $(<1$ year) population because anti- toxins derived from equine plasma (such as HBAT) have shorter half-life, and have been associated with anaphylaxis, delayed allergic reactions (serum sickness), and lifelong sensitization to equine proteins [19].

However, American clinicians negatively report on HBAT derived from the plasma of immune horses and administer it exceedingly rare; some authors point out that the use of these drugs in no serious case of the disease did not lead to rapid reversal of the process [20], therefore has limited therapeutic potential in the presence of sufficiently pronounced side effects. In addition, heterogeneous serums can also cause other dangerous complications that may outweigh their use [21], which suggests that glucocorticoids should be administered simultaneously with it. More promising and safe is the administration of human specific immunoglobulin or native homologous plasma [22]. Data from the Ministry of Health of Ukraine for the last 10 years show that when there was an intermittent availability of HBAT, the mortality rate from botulism was increased significantly - from 1.50 (2005) to $9.25 \%$ (2017).

The late hospital admission of the patient (on the 3rd of the illness), the absence of HBAT (was administrated only on the 5th day of the illness) may have contributed to the development of such rare complications as atonic tetraparesis (hand weakness, moderate weakness of the lower extremities), dysmetabolic polyneuropathy of the lower limbs that lasted more than 2 months in the first patient. A similar case of developing tetanus tetraparesis and respiratory paralysis in botulism was described by S. Wendt et al. (2017) [15].

Hence, the administration of HBAT should be as early as possible, but the cases described have demonstrated that even the late administration of specific antitoxin on the 5th day of the disease in the first case and on the 6th day of the disease in the second case had a significant positive therapeutic effect and contributed to the clinical recovery of the patients. Therefore, HBAT should be administered immediately upon the hospitalization to the clinic, regardless of the day of illness.

Standard therapy should also include antibiotics to inhibit the pathogen activity and toxin formation, especially with wound and infant botulism. It is advisable to use anticholinesterase drugs to improve neuromuscular conductivity, but it does not always produce the desired effect. The average cost of treatment for a patient with botulism in the US is estimated at 10 thousand dollars [23].

\section{Conclusions}

1. Characteristic symptoms of botulism are sometimes absent, for example, the inability to read the fine print, which is a significant challenge in diagnosing the disease.

2. Atonic tetraparesis, dysmetabolic polyneuropathy of the lower extremities may be occasionally developed as a complication of botulism.

3. In case of suspicion of botulism, even with a fuzzy epidemiological anamnesis and an unusual clinical picture, a targeted, specific examination and immediate administration of antitoxins are indicated.

4. The heptavalent botulinum antitoxin has a significant clinical effect, contributes to recovery even at the late stages of a patient hospitalization. 
Prospects for further research. Knowledge about botulism and administration of the heptavalent botulinum antitoxin will allow practitioners to use up-to-date diagnostic and treatment methods in a timely manner for preventing complications and rapid elimination of toxins.

Conflicts of interest: authors have no conflict of interest to declare. Конфлікт інтересів: віАсутній.

Надійшла Ао реАакції / Received: 22.05.2019

Після Аоопрацювання / Revised: 16.08.2019

Прийнято АО Аруку / Accepted: 05.09.2019

Information about authors:

Ivakhiv O. L., MD, PhD, Associate Professor of the Department of Infectious Diseases and Epidemiology, I. Horbachevsky Ternopil National Medical University, Ukraine.

Vyshnevska N. Yu., MD, PhD, Assistant of the Department of Infectious Diseases and Epidemiology, I. Horbachevsky Ternopil National Medical University, Ukraine.

\section{Відомості про авторів:}

Івахів 0. ^., канА. меА. наук, Аоцент каф. інфекційних хвороб з епідеміологією, шкірними та венеричними хворобами, Тернопільський національний медичний університет імені І. Я. Горбачевського, Україна.

Вишневська Н. Ю., канА. меА. наук, асистент каф. інфекційних хвороб з епіАеміологією, шкірними та венеричними хворобами, Тернопільський національний меАичний університет імені І. Я. Горбачевського, Україна.

\section{Сведения об авторах:}

Ивахив О. ^., канА. меА. наук, Аоцент каф. инфекционных болезней с эпиАемиологией, кожными и венерическими болезнями, Тернопольский национальный медицинский университет имени И. Я. Горбачевского, Украина. Вишневская Н. Ю., канА. меА. наук, ассистент каф. инфекционных болезней с эпиАемиологией, кожными и венерическими болезнями, Тернопольский национальный медицинский университет имени И. Я. Горбачевского, Украина.

\section{References}

[1] Jeffery, I. A., \& Karim, S. (2017). Botulism. StatPearls. [Internet]. Treasure Island (FL): StatPearls Publishing. https://www.ncbi.nlm.nih. gov/books/NBK459273/

[2] Schulte, M., Hamsen, U., Schildhauer, T. A., \& Ramczykowski, T. (2017). Effective and rapid treatment of wound botulism, a case report. BMC Surgery, 17(1). https://doi.org/10.1186/s12893-017-0300-4

[3] Jackson, L., Madan-Khetarpal, S., Naik, M., Michaels, M., \& Riley, M. (2017). Infant Botulism in the Very Young Neonate: A Case Series. American Journal of Perinatology Reports, 7(3), e163-e166. https://doi.org/10.1055/s-0037-1604407

[4] Kopcha, V. S., \& Borak, V. T. (2014). Vypadok iniektsiinoho botulizmu. [Case of injection botulism]. Infektsiini khvoroby, (4), 88-90. [in Ukrainian].

[5] You, G., Khan, A., Shor, J., \& Forester, G. P. (2016). Rapidly Progressive Muscle Paralysis and Acute Respiratory Failure Following Endoscopic Botulinum Toxin Injection. ACG Case Reports Journal, 3(1), Article e166. https://doi.org/10.14309/cri.2016.139

[6] Rafie, S., Salmanzadeh, S., Mehramiri, A., \& Nejati, A. (2017). Botulism Outbreak in a Family after Ingestion of Locally Produced Cheese. Iran Jornal of Medical Sciences, 42(2), 201-204.

[7] Mezencev, R., \& Klement, C. (2017). Foodborne botulism - a re-emerging public health challenge. Epidemiologie, Mikrobiologie, Imunologie, 66(1), 39-48. [in Czech].

[8] Shaffer, N., Wainwright, R. B., Middaugh, J. P., \& Tauxe, R. V. (1990). Botulism among Alaska Natives. The role of changing food preparation and consumption practices. Western Journal of Medicine, 153(4), 390-393.

[9] Gao, Q. Y., Huang, Y. F., Wu, J. G., Liu, H. D., \& Xia, H. Q. (1990). A review of botulism in China. Biomedical and Environmental Sciences, 3(3), 326-336.
[10] Centers for Disease Control and Prevention (CDC). (2007). Botulism associated with commercially canned chili sauce - Texas and Indiana, July 2007. Morbidity and Mortality Weekly Report (MMWR), 56(30), 767-769.

[11] Sobel, J., Tucker, N., Sulka, A., McLaughlin, J., \& Maslanka, S. (2004). Foodborne Botulism in the United States, 1990-2000. Emerging Infectious Diseases, 10(9), 1606-1611. https://doi.org/10.3201/ eid1009.030745

[12] Centers for Disease Control and Prevention (CDC). (2019). Botulism Annual Summary, 2017. Atlanta, Georgia: U.S. Department of Health and Human Services, CDC. Reviewed January 15, 2020. https://www. cdc.gov/botulism/surv/2017/index.html

[13] McLauchlin, J., Grant, K. A., \& Little, C. L. (2006). Food-borne botulism in the United Kingdom. Journal of Public Health, 28(4), 337-342. https:// doi.org/10.1093/pubmed/fdl053

[14] HPA Centre for Infections. (2009, March 31). Guidelines for Action in the Event of a Deliberate Release: Botulism, Version 4.5.1. https:// webarchive.nationalarchives.gov.uk/20140714110822/http://www.hpa. org.uk/webc/HPAwebFile/HPAweb_C/1194947315628

[15] Public Health England. (2014, January 31). Foodborne Botulism Laboratory reported cases of Clostridium botulinum intoxication reported to Public Health England, England and Wales 1980 - 2013. https://webarchive.nationalarchives.gov.uk/20140714110800/http://www.hpa.org.uk Topics/InfectiousDiseases/InfectionsAZ/Botulism/EpidemiologicalData/ botu010FoodborneBotulismLaboratoryreportedcases/

[16] Drivenes, B., Krause, T. G., Andersson, M., Müller, L., Fuursted, K., Pedersen, T., Hansen, A. K., \& Børresen, M. L. (2017). Infant botulism in Denmark from 1995 to 2015. Danish Medical Journal, 64(9), Article A5404.

[17] Gutmann, L., Bodensteiner, J., \& Gutierrez, A. (1992). Electrodiagnosis of botulism. The Journal of Pediatrics, 121(5), Article 835. https://doi. org/10.1016/s0022-3476(05)81936-5

[18] Roman, M. G., Humber, J. Y., Hall, P. A., Reddy, N. R., Solomon, H. M., Triscott, M. X. Beard, G. A., Bottoms, J. D. Cheng, T., \& Doellgast, G. J. (1994). Amplified Immunoassay ELISA-ELCA for Measuring Clostridium botulinum Type E Neurotoxin in Fish Fillets. Journal of Food Protection, 57(11), 985-990. https://doi.org/10.4315/0362-028x-57.11.985

[19] Arnon, S. S., Schechter, R., Maslanka, S. E., Jewell, N. P., \& Hatheway, C. L. (2006). Human Botulism Immune Globulin for the Treatment of Infant Botulism. New England Journal of Medicine, 354(5), 462-471. https://doi.org/10.1056/nejmoa051926

[20] Nikiforov, V. V., Tomilin, Yu. N., Chernobrovkinya, T. Ya., Yankovskaya, Y. D., \& Burova, S. V. (2019). Trudnosti rannei diagnostiki i lecheniya botulizma [The difficulties of early diagnosis and treatment of botulism]. Arhiv" vnutrennej mediciny, (4), 253-259. https://doi. org/10.20514/2226-6704-2019-9-4-253-259 [in Russian].

[21] Kyrychenko, P. D., Voinalovych, O. O., \& Kostur, M. Y. (2001). Profilaktyka uskladnen seroterapii pry botulizmi. [Neuroinfections. Other infectious diseases]. Neiroinfektsii. Inshi infektsiini khvoroby. Proceedings of the Scientific and Practical Conference and Plenum of Ukrainian Association of Infectionists (pp. 70-71). Ukrmedknyha. [in Ukrainian].

[22] Pak, S. G., Kokoreva, L. N., \& Shuba, L. I. (2005). Botulizm [Botulism] Meditsinskaya pomoshch', (1), 43-45. [in Russian].

[23] Maliy, V. P. (2012). Pishchevoi botulizm. [Food botulism]. Klinichna imunolohiia. Alerholohiia. Infektolohiia, (3), 15-25. [in Russian]. https:// kiai.com.ua/ru-issue-article-727/Pishchevoy-botulizm 